\title{
The Multi-Millennial Olive Agroecosystem of Salento (Apulia, Italy) Threatened by Xylella Fastidiosa Subsp. Pauca: A Working Possibility of Restoration
}

\author{
Marco Scortichini \\ CREA-Council for Agricultural Research and Economics, Research Centre for Olive, Fruit and Citrus Crops, \\ Via di Fioranello 52, I-00134 Roma, Italy; marco.scortichini@crea.gov.it
}

Received: 3 July 2020; Accepted: 12 August 2020; Published: 19 August 2020

\begin{abstract}
In Salento, the olive agro-ecosystem has lasted more than 4000 years, and represents an invaluable local heritage for landscape, trade, and social traditions. The quarantine bacterium Xylella fastidiosa subsp. pauca was introduced in the area from abroad and has been widely threatening olive groves in the area. The successful eradication of quarantine phytopathogens requires a prompt identification of the causative agent at the new site, a restricted infected area, a highly effective local organization for crop uprooting and biological features of the micro-organism that would guarantee its complete elimination. However, at the time of the first record, these criteria were not met. Interdisciplinary studies showed that a zinc-copper-citric acid biocomplex allowed a consistent reduction of field symptoms and pathogen cell concentration within infected olive trees. In this perspective article, it is briefly described the implementation of control strategies in some olive farms of Salento. The protocol includes spray treatment with the biocomplex during spring and summer, regular pruning of the trees and mowing of soil between February and April to reduce the juvenile of the insect vector(s). Thus far, more than 500 ha have begun to follow this eco-friendly strategy within the "infected" and "containment" areas of Salento.
\end{abstract}

Keywords: landscape; local heritage; olive quick decline syndrome; rural sustainability; pathogen control strategy

\section{The Olive Agro-Ecosystem of Salento}

According to the Critical Ecosystem Partnership Fund (CEPF), the plant biodiversity of the Mediterranean Basin is the second largest biological hotspot in the world and the third in terms of plant diversity [1]. In many areas of the Basin, the olive (Olea europea subsp. europea) is cultivated as a typical agricultural crop with a regular spacing between trees, a well-defined shape of the crown formed by pruning, and with the regular supply of fertilizers and agrochemicals. However, in other areas, the olive is grown in a more traditional way so that it can be considered a natural element of the Mediterranean landscape and environment [2]. Notably, these natural olive groves portray the same floristic composition found in wild Mediterranean sites [3,4]. Among these areas, the Salento peninsula (Apulia region, southern Italy) is a particular territory where olives have been cultivated since the Bronze Age [5]. Nowadays, with more than 11 million trees within the Lecce, Brindisi and Taranto provinces, olives are present almost everywhere. At some sites, it is even possible to observe many thousands of olive groves over many kilometers, and many centuries-old olive trees are also present in the area which contribute to a typical agro-ecosystem for the Mediterranean Basin [6] (Figure 1). 


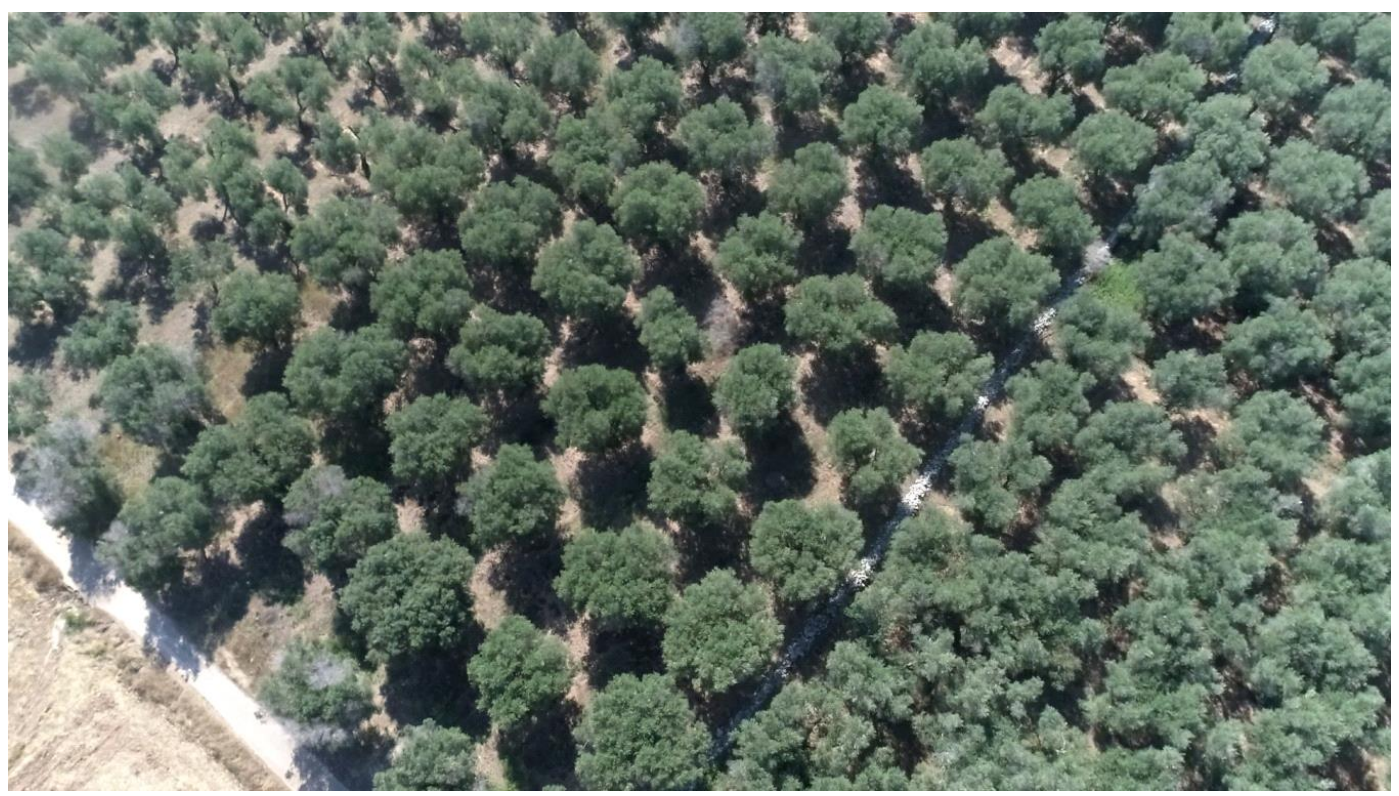

Figure 1. The olive agro-ecosystem of Salento has lasted more than 4000 years and the trees cover the vast majority of the territory. Centuries-old trees are on the right.

The history of olive cultivation in Salento is particularly interesting since it reflects old and recent traditions-rules that deeply influenced how farmers have grown olive trees, produced oil, adopted particular agronomical techniques, and have maintained the original landscape throughout the centuries. After the Bronze and Iron Ages, the Phoenicians and Greeks re-introduced the cultivation of olives in many areas of the Mediterranean Basin. Ancient Rome largely favored the establishment of olive cultivation in Salento [7], and all Apulia became the main source of oil for Rome and its territory during the entire republican period [8]. Afterwards, during the 8th century, a new impulse for olive and oil production was introduced by Basilian monks, who, escaping from the Byzantine empire, settled in Salento and dedicated their particular attention to olive cultivation to produce high quality oil [9]. During the Middle Ages, under the Normans and following Swabian dominations as well as Angevin and Aragonese epochs later, the olive became the predominant tree in Salento that continued to represent a relevant area for high-quality oil production $[10,11]$. The practice of grafting wild olive trees with clonal local and foreign cultivars spread over the territory, and many olive groves were framed by the characteristic white dry stone walls (i.e., clausure olivarum) [8] that continue to persist today at a large scale (Figure 2).

Salento, in addition to the production of oil for a comestible, became the most important area for the worldwide production of lamp oil developed in the characteristic hypogeum oil mills. During the 16th-18th centuries, the most finest lamp oil reached all major areas of Italy and Europe, including Russia and North America from the Gallipoli port [12]. Later on, Bourbons deeply influenced the further extension and cultivation of olive trees in the Salento peninsula; the date of May 30, 1787 represents the beginning of a further spreading of the olive crop. The rulers, indeed, proclaimed that for 40 years, no tax was due in the case of the development of a new olive plantation, inciting a relevant increase in oil production [13]. In modern times, the Council Regulation (EC) 2012/2006, Standard 4.3 of 29th December 2006 within the Good Agricultural and Environmental Conditions (GAEC) concerning the "maintenance of olive groves in good vegetative condition", links the welfare payment by the European Union to farmers for maintaining the cultivation land and olive trees through weed elimination and occasional pruning. Two main olive cultivars are grown in Salento, namely "Ogliarola salentina" and "Cellina di Nardò" characterized by their high nutritional olives very rich in polyphenols and carotenoids [14,15], and they are reported as largely spread in Salento at least since the ancient Roman Republic [7]. 


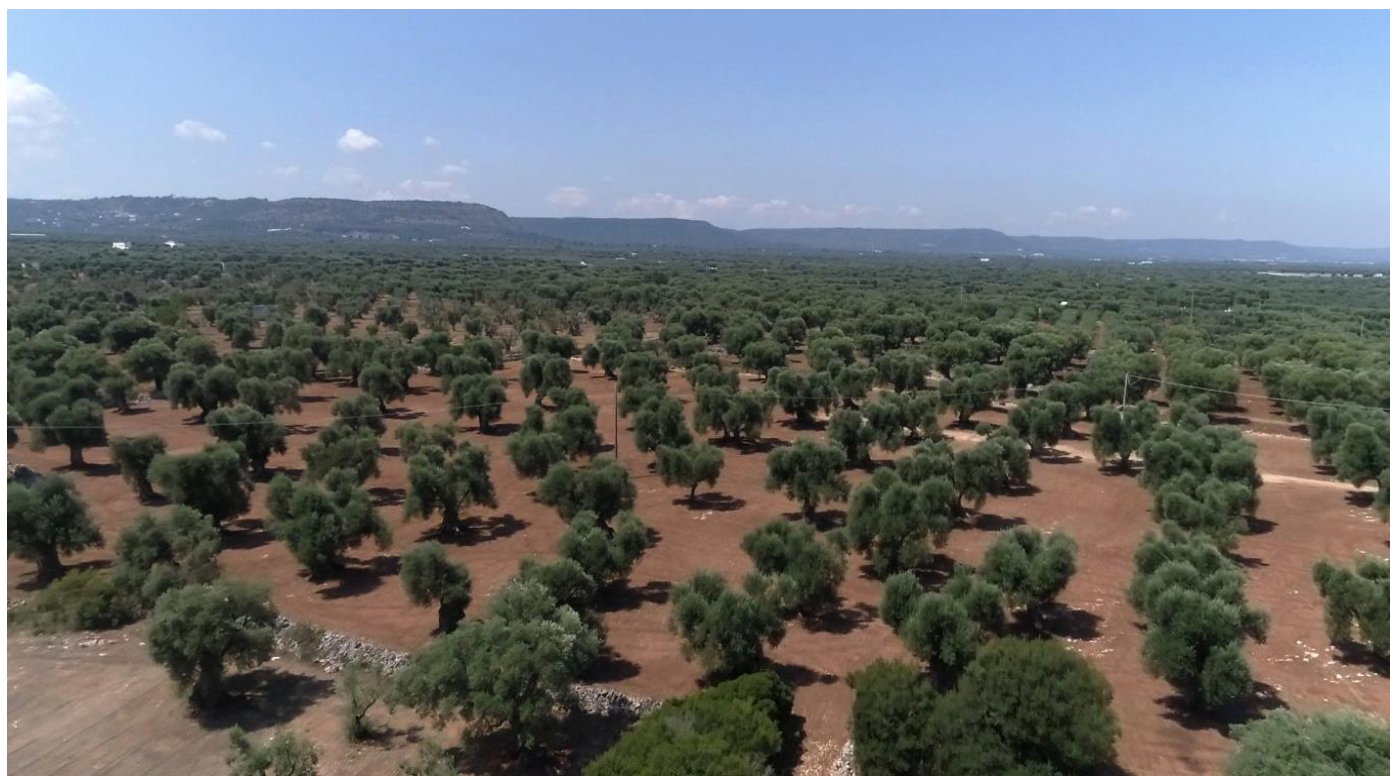

Figure 2. A view of the olive agro-ecosystem of Salento with the typical white dry stone wall (on the left).

The combination of all these features strongly contribute to making Salento a remarkable agro-ecosystem that strings together history, landscape, trade and social traditions linked by olive cultivation, and thus represents a remarkable resource for the entire territory. In the past, the integrity of the agro-ecosystem was disturbed by foliage disorders that by the end of the 18th century and start of the 20th caused extensive damage to olive trees mainly grown in the western part of the Salento Peninsula. The leaf scorch observed in Salento was caused by a disturbance in the water supply of olive trees, nutrient deficiency or by hot, dry or salty winds as well as by weak fungal pathogens such as Stictis panizzei [16]. However, the olive agro-ecosystem was re-established to its previous integrity in both the periods.

\section{A Threat from Abroad: The Quarantine Phytopathogen Xylella Fastidiosa}

Currently, this agro-ecosystem is more severely threatened by the occurrence of the plant quarantine bacterium Xylella fastidiosa, firstly detected in the olive agro-ecosystem on October 2013 [17]. Subsequently, the pathogen was isolated from olive trees showing symptoms of the so-called "olive quick decline syndrome" (OQDS) such as leaf scorch, twig and branch die-back, and tree death (Figure 3).

On the basis of genome sequence comparison, the isolates were identified as X. f. subsp. pauca [18]. At the time of the first record, the disease was found on approximately 8000-10,000 ha within the Salento area of Gallipoli and the nearby municipalities (Lecce province, Apulia region, southern Italy) [18]. It is now estimated that, by the end of 2017, the infection has spread to more than 53,500 ha and to approximately 6.5 million olive trees, including many centuries-old trees [19] (Figure 4).

$X$. fastidiosa was a pathogen mainly found in North, Central and South America where it causes severe economic losses to a vast array of cultivated crop and forest species [20]. The occurrence of this pathogen in a new area far from its usual habitats was most likely due to the global circulation of plant material that frequently allows the introduction of insect pests and pathogens into new countries [21]. In the case of X. f. subsp. pauca infecting olives in Salento, its introduction likely occurred through the import of coffee plants from Costa Rica in previous years [22,23]. It is possible that, upon the arrival, the X. f. subsp. pauca vector meadow spittlebug, Philaenus spumarius, transmitted the bacterium cells from the coffee plant leaves to the olive trees of Salento [24]. 


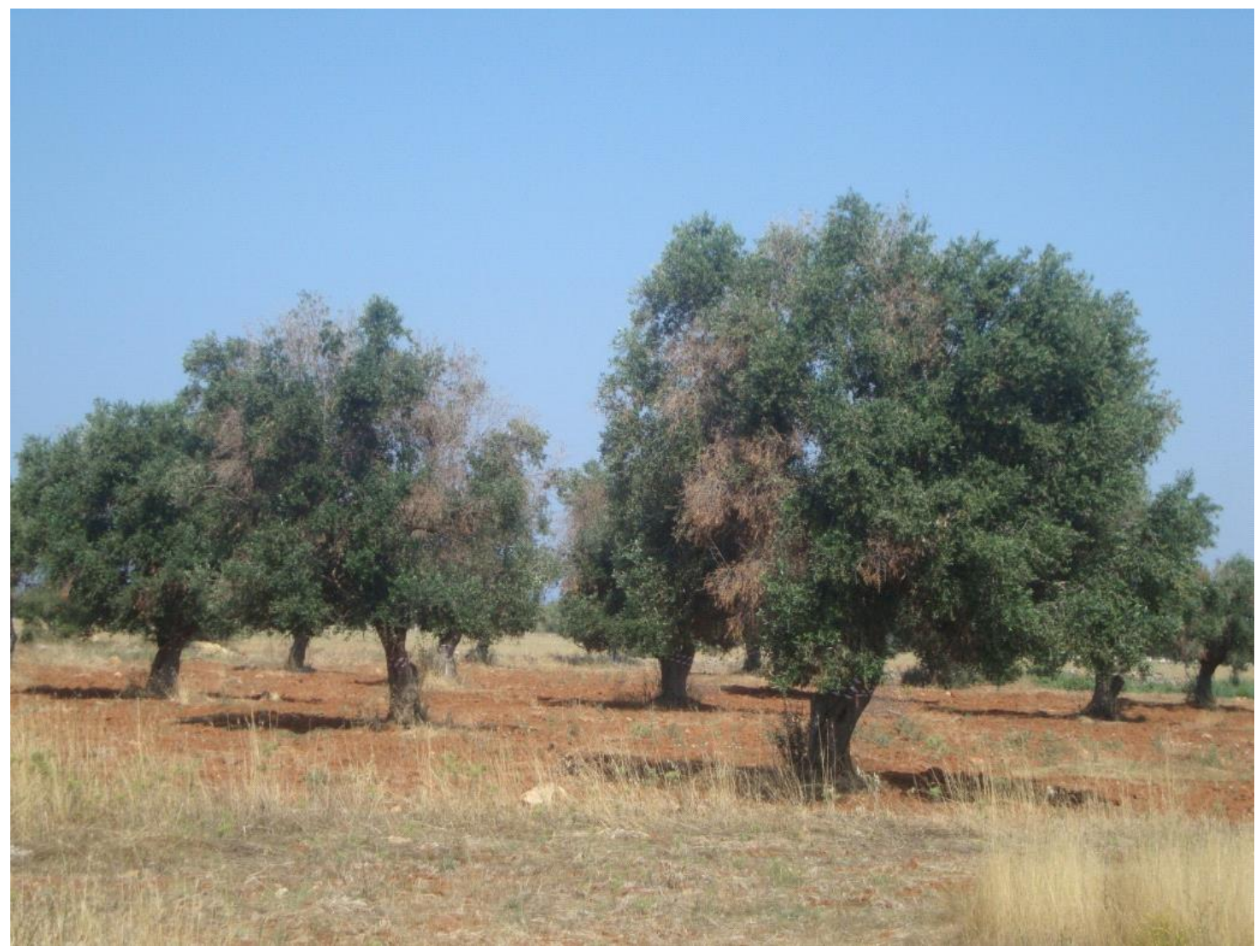

Figure 3. Leaf, twig and branch die-backs are the main symptoms of the "olive quick decline syndrome" caused by Xylella fastidiosa subsp. pauca in olive agro-ecosystems of Salento.

In Europe, quarantine phytopathogens never recorded previously in a country are ruled by mandatory recommendations that aimed at rapidly eliminating the cause of the infection in the territory. However, the successful eradication of quarantine phytopathogens requires various criteria: (a) a prompt identification of the causal agent found in a new site, (b) a restricted and limited infected area, (c) an effective local organization for crop uprooting, and (d) biological features of the micro-organism that guarantee its complete elimination [25].

Unfortunately, at the time of the record of X. f. subsp. pauca on olive trees in Salento, none of these criteria were met. In particular, the first sign of olive tree die-back were noticed in the Gallipoli area five to six years before the official case record of 2013 [26], and when the bacterium was isolated and identified it had already colonized approximately $8000-10,000$ ha $[18,25]$ infecting approximately $1,000,000$ olive trees. In addition, X. fastidiosa can survive on a multitude of wild and cultivated plant species [27,28], it is transmitted by insect vectors particularly prolific [29] and, in the case of X. f. subsp. pauca, the vector meadow spittlebug is widespread and increasing in the territory [30]. It appears to be quite evident within this scenario, that the eradication (i.e., the complete elimination of the pathogen from the infected area) [31] is impossible [32]. Consequently, as for emerging human pathogens [33], the search for an effective control strategy and, in this specific case, the accurate vector limitation in both infected and bordering areas, would seem more appropriate to contain the pathogen and safeguard the invaluable agro-ecosystem previously described.

The European Union delimits different areas as "infected", "containment" and "buffer" through Implement Decisions according to the spread and severity of the quarantine pathogen infection. The "containment" and "buffer" areas border the limits of the "infected" area, and the location of the areas in the territory can be displaced according to the occurrence of the new foci of the disease. Concerning OQDS, the "infected" area is where the initial outbreaks of the disease were observed 
and where the infection has widely spread. In this area, due to the occurrence of the vector and the very high and uniform density of olive orchards, the eradication of the pathogen has not been feasible. This area includes most of the Salento olive agro-ecosystem. Within the $20 \mathrm{~km}$-wide "containment" area bordering the northern limit of the "infected", each olive tree found to be infected by X. f. subsp. pauca must be uprooted in accordance with the European quarantine legislation. Within the nearer $10 \mathrm{~km}$-wide "buffer" area, more severe rules are applied, and within a radius of $100 \mathrm{~m}$ that starts from the infected tree, all olive trees must be uprooted (Figure 5).

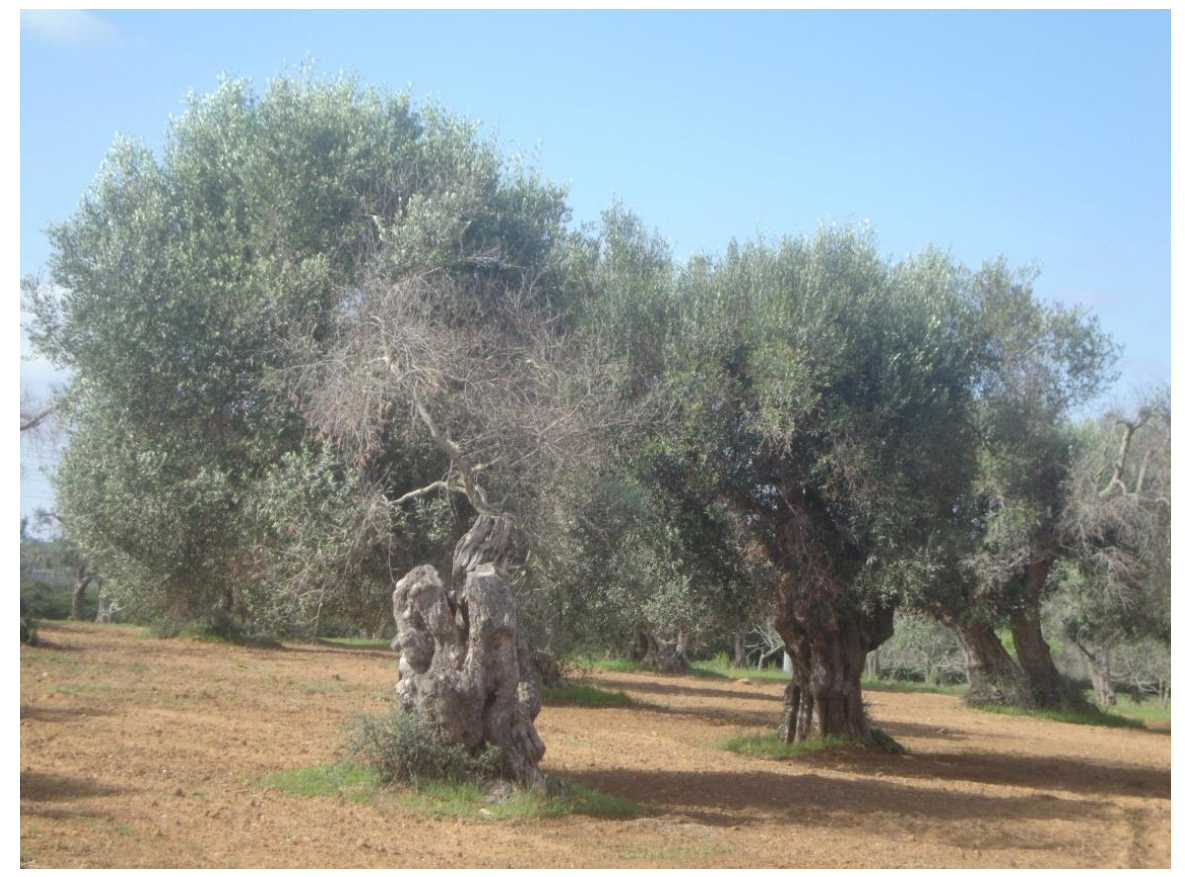

Figure 4. Centuries-old olive trees in Salento showing extensive die-backs upon the introduction of Xylella fastidiosa subsp. pauca from abroad.

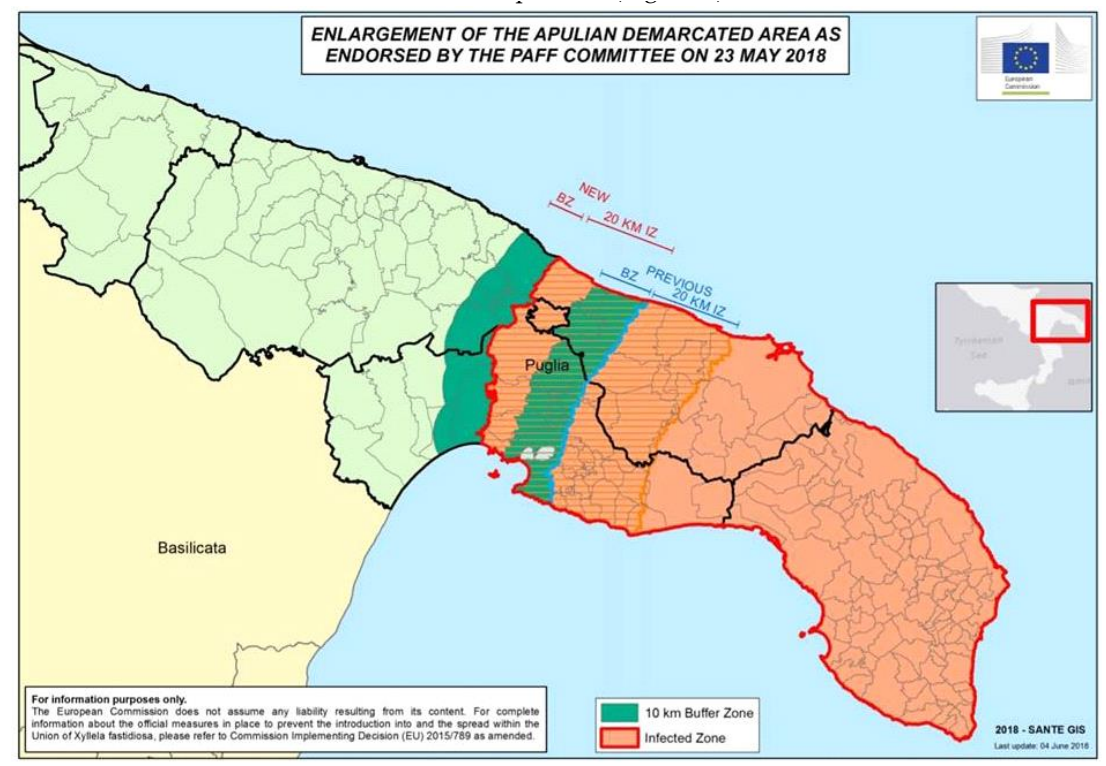

Figure 5. The mandatory Implement Decisions of the European Union establishing the "infected", "containment" and "buffer" areas in Apulia to limit the spread of Xylella fastidiosa subsp. pauca northward. Note that the zones can be changed according to the progression of the disease. 


\section{The Challenge of Controlling a Xylem-Limited Bacterial Plant Pathogen}

$X$. fastidiosa lives and multiplies exclusively within the plant xylem tissue where, by forming biofilms, impedes the normal water displacement from the roots to the aerial part of the tree, causing leaf and twig wilting and, subsequently, tree die-back [34]. This particular feature complicates reaching the pathogen with compounds that can effectively limit its further multiplication within the tree xylem vessels so to avoid the wilting of the plant. For many years, such a feature has strongly limited the search for compounds enabling the control of this bacterium to the point where the concept, "there is no cure for Xylella fastidiosa" has become a dogma in plant pathology. This concept has been extensively passed to the Salento farmers; this causing, in most cases, the olive groves' abandonment, so that a large part of the territory currently appears devastated.

However, a rationale for its control has been proposed by some researchers who, as for Pierce's disease of grapevine caused by X. f. subsp. fastidiosa, mention that: "if methods could be developed to effectively deliver prophylactic or therapeutic bactericides into grapevine, this could provide a comparatively straightforward solution to a very complex disease problem" [35].

Some preliminary studies have been performed pointing at investigating the potential of some compounds to inhibit the in vitro growth of X. fastidiosa [36-38] or at assessing putative microbial biocontrol agents [39]. However, none of them achieved conclusive results on the possibility of practical application in the field to control the bacterium.

Among the possible field control strategies, a rational one has been followed based on the potential capability to deliver an eco-friendly and internationally patented formulation, also suitable for organic farming into olive xylem tissue, and effectively limit the multiplication of $X$. fastidiosa within its niche by the release of certain ions. Some studies indicated that the manipulation of the mineral status of the host plant could be used as a disease management strategy for the control of this bacterium [40]. In particular, copper and zinc were the most effective ions in reducing the pathogen multiplication and biofilm formation when added in the growth medium (i.e., PD2 broth) at a dose of $0.25 \mathrm{mM}$ and $>200 \mu \mathrm{M}$, respectively [41]. In addition, it has been shown that zinc concentration usually found within the xylem acts as a pre-formed defense for the plant in case of pathogen attack, and thus, zinc detoxification in the host plant is required for triggering the full virulence of the pathogen [40]. Consequently, a supplemental supply of such an ion within the leaf could impede its detoxification in planta, avoiding the further pathogen multiplication and host colonization.

Within the abovementioned framework, it has been performed a three-year study assessing the possible use of a zinc $(4 \% w / w)$-copper $(2 \% w / w)$-citric acid patented biocomplex, namely Dentamet ${ }^{\circledR}$ (Diagro srl, Italy), as a tool in controlling the OQDS in Salento. This was performed in an olive orchard of the Lecce province planted with 70-year-old trees of the local cultivars "Ogliarola salentina" and "Cellina di Nardò". Dentamet ${ }^{\circledR}$ biofertilizer is obtained via an electrolytic process of zinc and copper salts that are subsequently complexed with hydracids of citric acid through a fermentative process similar to those released by some fungi in nature. The olive orchard was selected based on the occurrence of the pathogen at the site as officially detected just prior to initiating the trial. The biocomplex was sprayed to the olive crown six times (once per month) during spring and summer (from April to September) at a dose of 0.5\% (v:v) [42]. The reduced amount of the active ingredients, i.e., zinc and copper, and the low dose with which they were sprayed fully satisfied the current requirements decreed by the European Union to avoid copper accumulation in the soil (i.e., $4 \mathrm{~kg} / \mathrm{ha}$ per year).

\section{The Interdisciplinary Approach to the Study}

To fully assess the potential capacity of the biocomplex in controlling the pathogen, a series of studies involving different disciplines were undertaken to investigate several features: (a) its bactericidal activity, (b) its capacity to effectively reach the xylem network of the leaf, twig and young branch of the tree, (c) the effective release of zinc and copper within the xylem, (d) the significant reduction of field symptoms (i.e., twig and branch die-back), (e) the reduction of pathogen cell density 
within the foliage, (e) the absence of any phytotoxicity to the tree, and (f) the absence of zinc and copper residues in the oil.

The biocomplex displayed strong in vitro bactericidal activity towards X. f. subsp. fastidiosa [42] and X. f. subsp. pauca, sequence type 53, isolated in Apulia from olive, (Loreti S. and co-workers, Council for Research in Agriculture and Economics, Research Centre for Plant Protection and Certification, Roma, Italy, personal communication). In addition, the biocomplex showed a relevant in planta systemicity as observed by using confocal laser scanning microscopy and fluorescence quantification. The effective ionic release of zinc and copper within these samples was assessed using the inductively coupled plasma atomic emission spectroscopy. Upon the treatments with the biocomplex, microscopy assessment allowed to observe the effective reaching of leaf and twig xylem by the compound, whereas emission spectroscopy enabled to reveal significant greater values for zinc and copper ions within central veins of leaves and within petioles, and twigs. These results provided relevant information about the ability of the formulation to reach the olive xylem network and therein act as an inhibitor of X. f. subsp. pauca multiplication.

Field efficacy was assessed along three consecutive years (2015-2017) by counting in each tree the new wilted twigs that appear from spring to autumn. Data were analyzed per each tree and by cultivar and were subjected to ANOVA and significance was evaluated for $p<0.05$. Mean values were compared by Fisher's LSD test. To further corroborate field data, the pathogen cell densities were assessed in four trees by quantitative real-time PCR. A significant reduction of field symptoms (i.e., twig and branch die-backs) was observed along each year and at the end of the trial. In addition, a reduction of the pathogen cell density compared with the control trees was also observed in the treated ones that had shown to contain significant lower X. f. subsp. pauca population (i.e., 100 colony-forming units) compared to untreated trees (i.e., from 10,000 to 100,000 colony-forming units) (Figure 6). The treatment did not incite tree phytotoxicity and no zinc and copper residues were found in the oil obtained from the trees that had received the spray treatments. It is worth noting the dramatic reduction of X. fastidiosa DNA concentration after the frost events of January 2017 and also to observe that the "Ogliarola salentina" untreated control tree was dead in December 2016, whereas "Cellina di Nardò" untreated control tree resulted almost totally withered in April 2017. During one year (i.e., 2017), the trees faced both extensive winter frost and a severe summer drought, this augmenting the stress in presence of the pathogen. Reproduced from [42].

To further corroborate such data, a subsequent and larger study was performed on two olive groves located at Cannole and Galatone within the "infected" area of the Lecce province. A total of 41 olive trees were thoroughly assessed by means of quantitative real-time PCR during 2019 (i.e., March, July, October). The study had the aim to verify the efficacy of the control strategy in the mid-term period. The two olive groves in Cannole and Galatone, indeed, applied the pathogen control strategy since 2016 and 2017, respectively. A very low pathogen cell concentration was found in both groves and in all the tested cultivars, namely "Ogliarola salentina", "Cellina di Nardò" and "Leccino" (Figure 7).

All the cultivars assessed, indeed, showed a decreasing of the pathogen cell concentration within the leaves along the seasons that resulted very low in both groves. It is worth noting that all the control (untreated) olive trees bordering such olive groves resulted dead before the final assessment (Loreti and co-workers, Council for Research in Agriculture and Economics, Research Centre for Plant Protection and Certification, Roma, Italy, personal communication). 


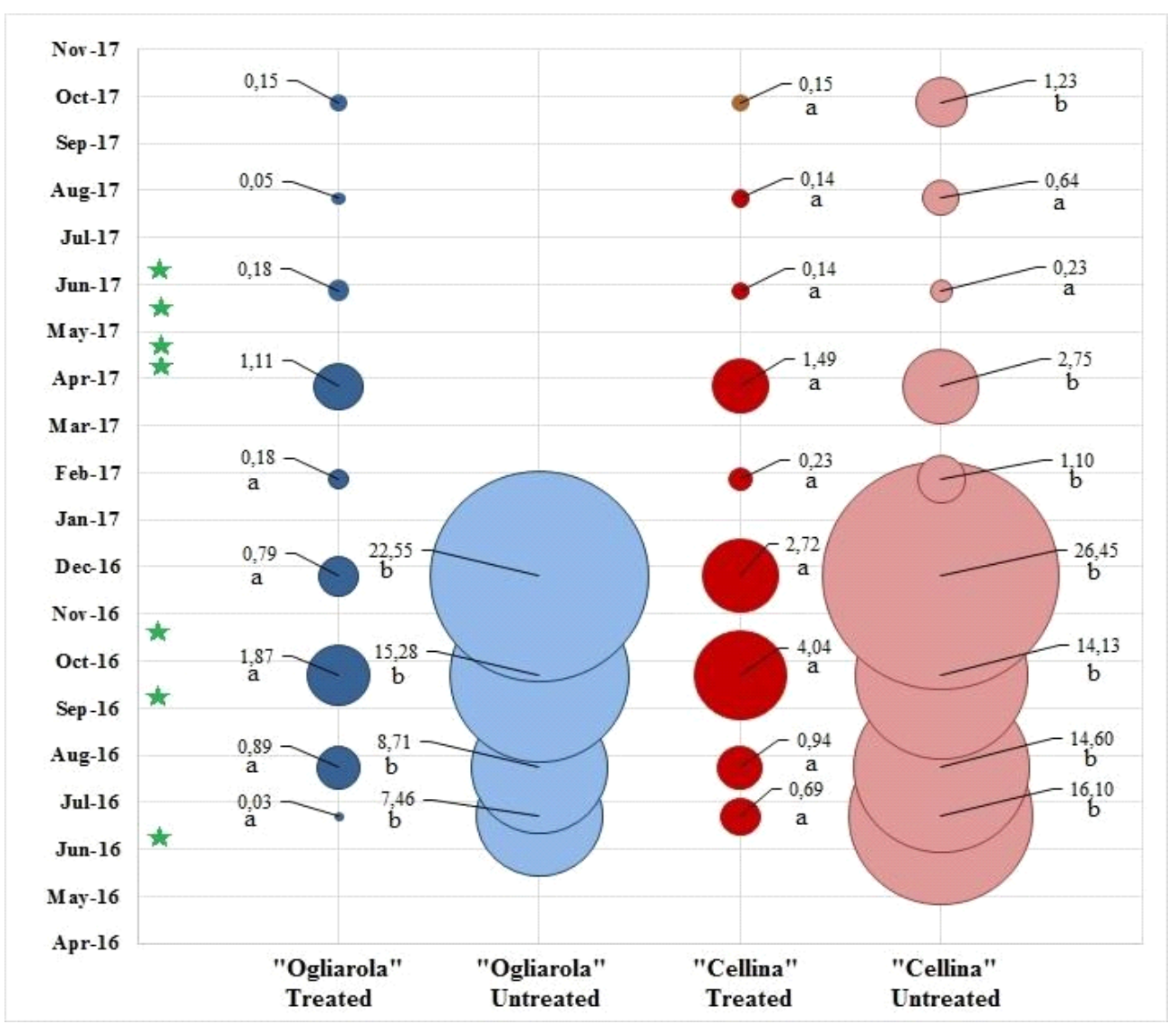

Figure 6. Xylella fastidiosa subsp. pauca DNA concentration detected by quantitative real-time PCR at each sampling and expressed as mean ng/tree, as obtained from June 2016 to September 2017.
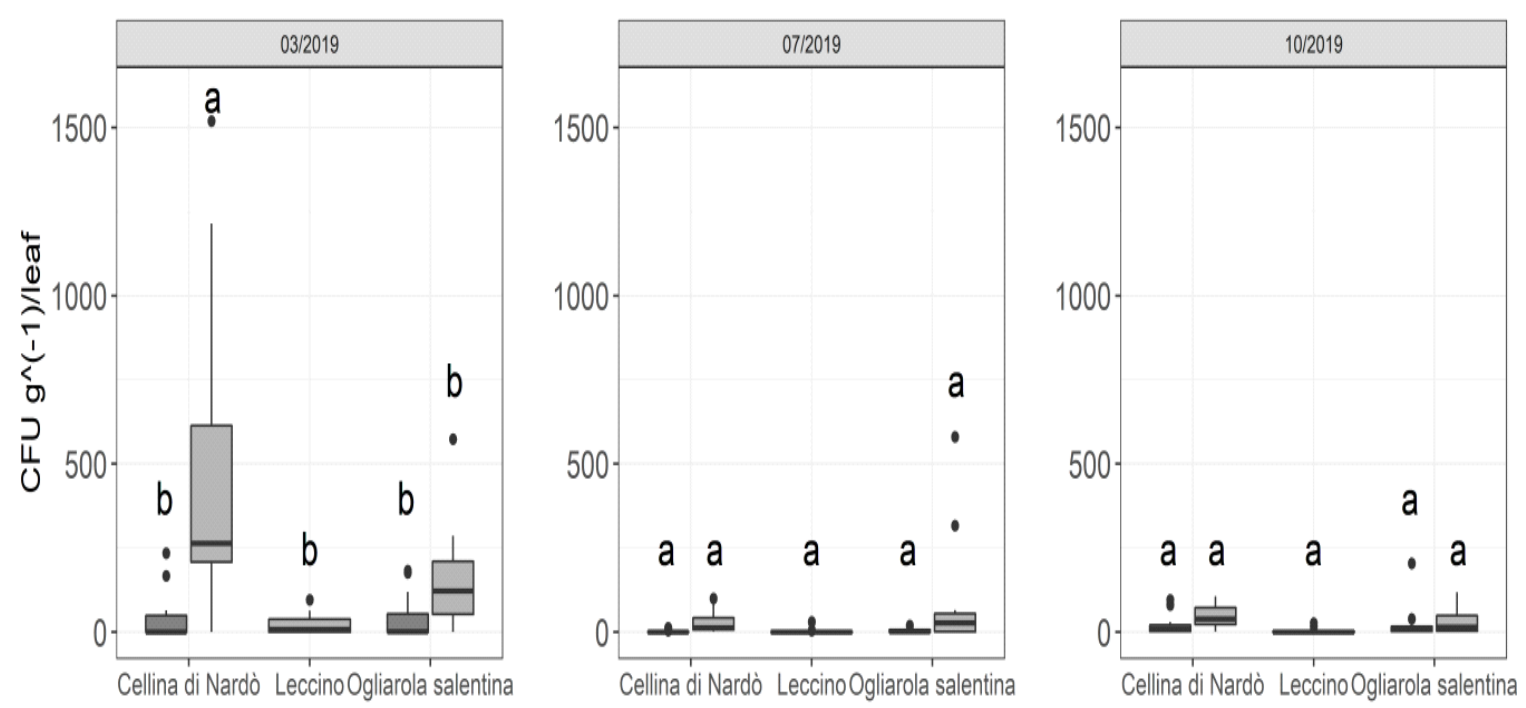

Cannole 追 Galatone

Figure 7. X. f. subsp. pauca DNA concentrations (CFU/g leaf) assessed by quantitative real-time PCR as observed during 2019 (i.e., in March, July and October) in 41 olive trees belonging to two orchards located at Cannole (Lecce province, 20 trees) and Galatone (Lecce province, 21 trees). 
In parallel, through a metabolomic approach using $1 \mathrm{H}-\mathrm{NMR}$, it has been observed that the biocomplex promptly induces a re-programming of the metabolic pathways in the infected trees that resulted in a relevant increased content of malic acid in "Ogliarola salentina" and in $\gamma$-aminobutyric acid (GABA) in "Cellina di Nardò" trees, respectively [43,44]. The involvement of micronutrients in the OQDS was also assessed by analyzing the in soil and in planta content in olive groves grown in the area where the syndrome was first observed. Olive trees grown in Gallipoli and nearby areas showing clear sign of OQDS were characterized by a lower micronutrient content in soil compared to other areas as well as a relevant leaf copper depletion [45]. These results reinforce the assumption that host micronutrients are deeply involved in the X. fastidiosa-host interaction and that their appropriate management could potentially provide a satisfactory bacterium control [46].

\section{Implementation of the Control Strategy in the Salento Olive Agro-Ecosystem}

These studies posed the basis for the application of the protocol to control X. f. subsp. pauca in olive farms. The control strategy is based on an eco-friendly management of the olive agro-ecosystem, and besides the spraying of the biocomplex to the crown, it includes the mowing of the soil during February-April to eliminate the weeds where the juvenile instars of the insect vector reside, as well as the regular and light pruning of the tree. The reduction of the vector population within the olive grove is another fundamental aspect to effectively control the bacterium. The eggs of P. spumarius hatch in February, and the juvenile instars inhabit weeds and herbs of the grove until the middle-end of April, when they move to olive leaves to initiate the spreading of the bacterium within the grove [47]. Therefore, the period between February-April is critical to eliminate the immotile instars by removing weeds and herbs using the mechanical mowing [48]. If this practice is regularly and timely performed on a large-scale basis in an area, it could potentially eliminate the use of insecticides to reduce the spread of adult insects during the following months. It should be stressed that weed removal is particularly critical when the adults start to move from weeds to olive foliage (i.e., end of April-early May) [49]. In addition, since this vector can spread the bacterium from May to October [49], soil tilling has been observed as very effective also in strongly reducing P. spumarius adults on the ground vegetation growing during the summer and autumn [50]. This last procedure, however, should be retained as complementary to the fundamental weed elimination of winter and spring [50]. Weeds should be removed also from hedges, ditches and walls often present in the olive groves. It is worth noting that in cases of mild winter, adult meadow spittlebugs can overwinter on the wild plants [30]. In such circumstances, an additional mowing carried out in winter seems worthwhile. It should be said that some cultivated crops of Leguminosae family, such as Medigaco sativa, Trifolium spp. and Vicia spp. are among the preferred plants for P. spumarius feeding [51]. Therefore, olive groves neighboring these plant species should have particular attention paid to the removal of weeds, trying to avoid the olive colonization from neighboring fields.

The regular pruning of trees is an important agronomical technique which allows the maintenance of a good balance between the vegetative and productive activity of the plant. Mainly due to the basic and simple requirements of the GAEC [52], however, this practice is performed in Salento every 4-5 years, inciting a premature aging of the tree and a risk due to the possible colonization of the large wounds by pathogens. In addition, the severe pruning of century-old trees infected by X. f. subsp. pauca, frequently causes trees to die in the following years [42,53]. To improve the use of the pruning techniques, we are promoting an annual round for re-establishing a more correct management of trees. This practice allows the elimination of exhausted twigs and branches, ensures a good airing of the crown and reduces the alternate bearing, therefore, increasing the tree longevity [54].

The maintenance or the restoration of a good soil fertility is also retained which is important to augment the effectiveness of the protocol. It has been, indeed, observed that the combination of the spray treatments to the crown with the biocomplex coupled with the distribution of an organic compound to the soil enhances the vegetative restart of the tree. It should be said that, in the last decades, the practices aiming at enhancing and/or maintaining a satisfactory level of soil fertility have 
been rather neglected in Salento area. By contrast, a large utilization of herbicides as a common practice in the olive groves has been observed [55]. The maintenance of specific microbial communities in the soil is retained as important to contain pathogen attacks [56]. Additionally, for the OQDS, the soil inoculation with a bio-fertilizer containing arbuscolar mycorrhiza fungi has induced a mitigation of the symptom [57]. The regular and coordinated application of these measures could allow either the maintenance of the healthy or the restoration of the partially diseased olive groves of Salento. It is important to stress that to ensure the success of the control strategy, it is fundamental to apply all of the measures we have described. There are many cases in the "infected" area, indeed, that single olive groves that are starting to apply the protocol are surrounded by olive trees severely damaged by OQDS, this representing a stable pathogen reservoir. It should be said, however, that when the infection has already withered most of the crown, it is not possible to completely restore the tree.

Currently, we can describe three different examples. Firstly, there are farms that are practicing the control strategy described above in the last five years. All of them are located in the "infected" area, within the provinces of Lecce and Taranto. Collectively, there are approximately 450 ha mainly planted with the local cultivars "Ogliarola salentina" and "Cellina di Nardò". The tree ages range from 30 to more than 200 years old and the yield range, according to the classical olive trend of yield (i.e., alternate bearing), from 40 to $60 \mathrm{q} . \mathrm{li} / \mathrm{ha}$ per year. The flowering and fruit setting were also relevant for the century-aged trees. During the last years, the occurrence of twig die-backs were rare and most of the trees did not show any symptoms. It should be stressed that the olive farms located in the province of Lecce are all surrounded by dead or severely damaged trees (Figures 8 and 9). This fact strongly reinforces the results obtained during our three-year study and would show that the consistent application of the control strategy enables the trees to survive and produce even within an infected area.

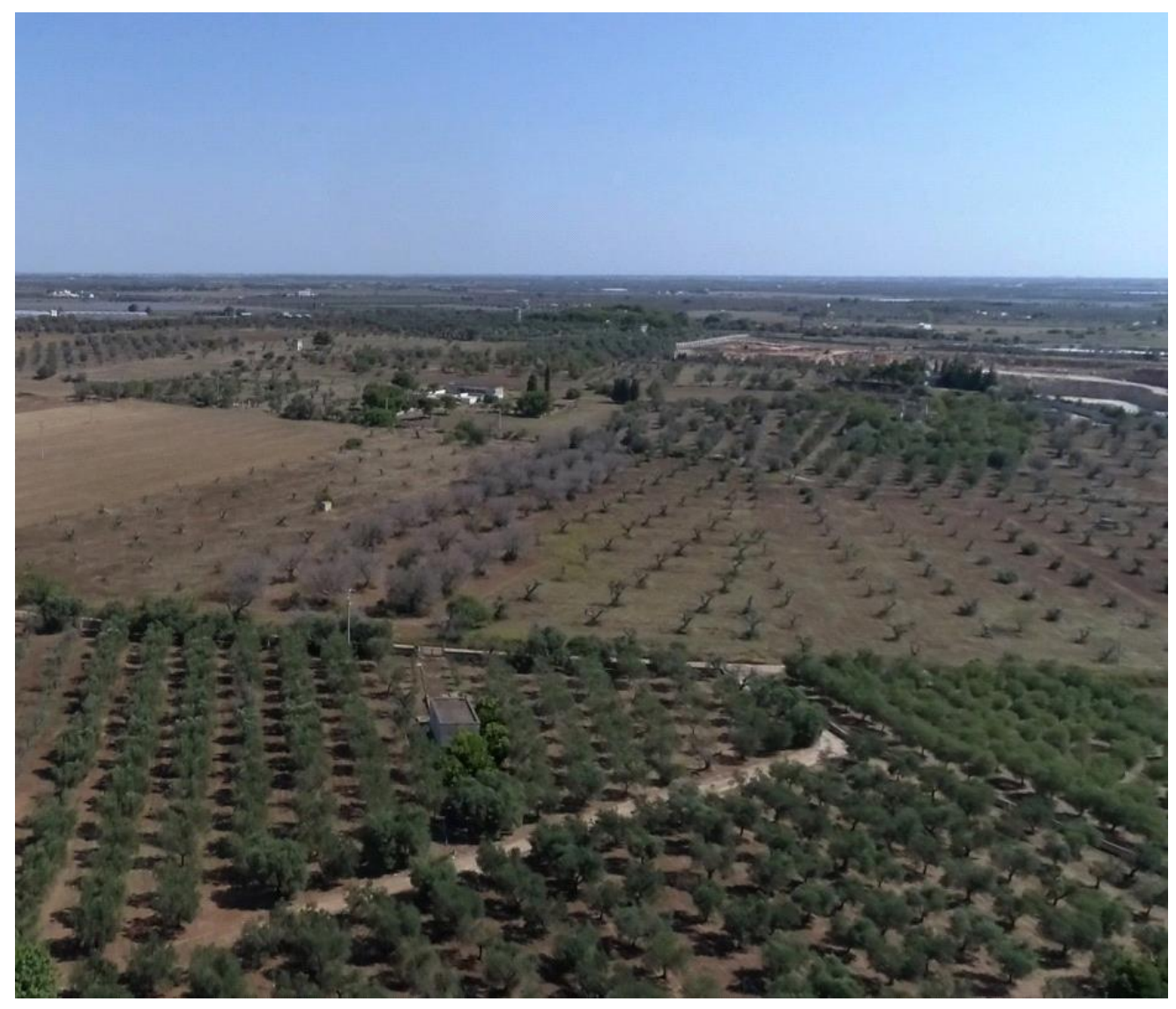

Figure 8. An olive grove located in Nardò (Lecce province; coordinates: Lat. 40.187637; Lon. 17.987413) that since 2016, is following the control strategy described in the text. It is located in the "infected" area, and borders a territory with dead or very damaged olive trees. 


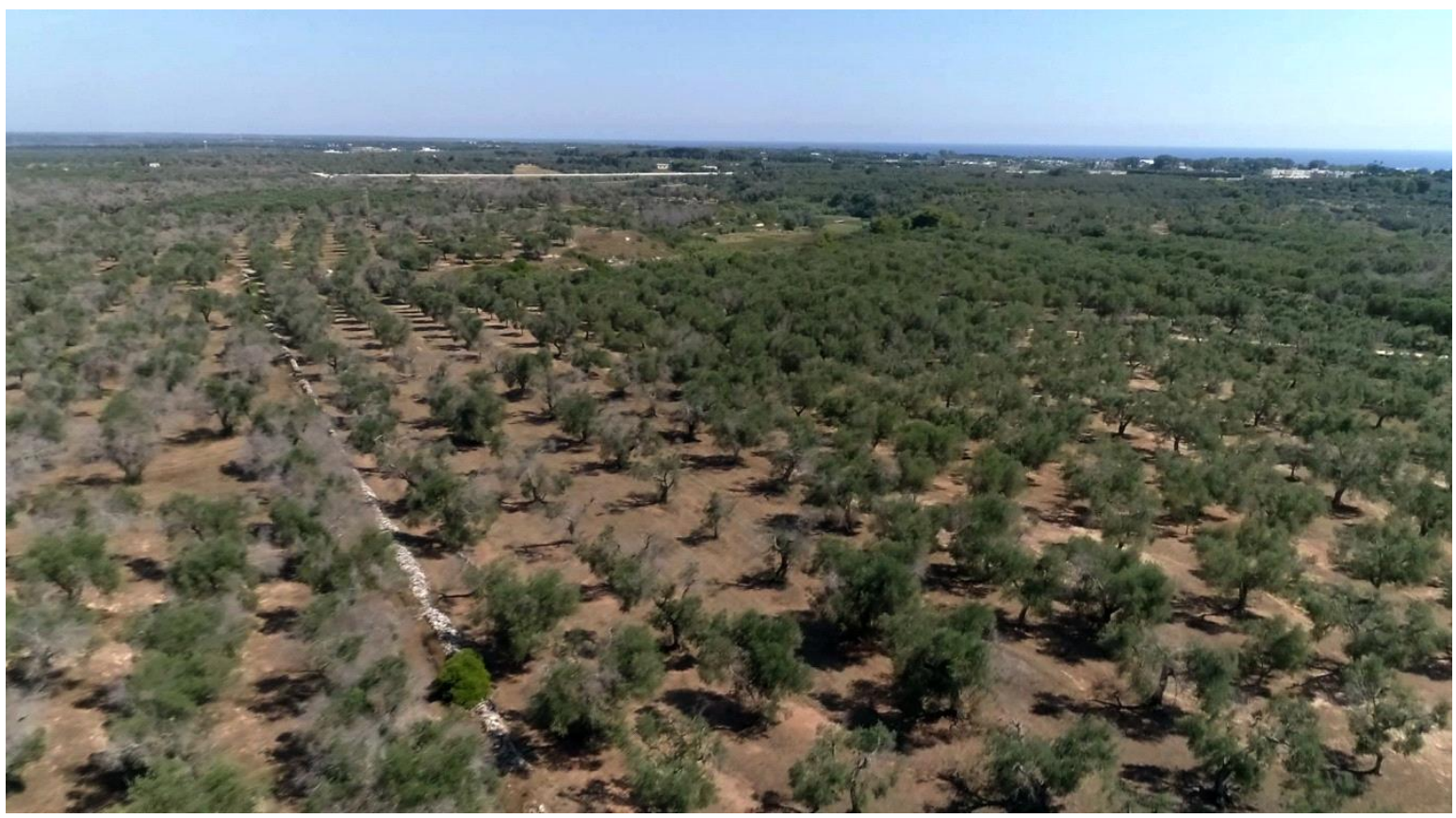

Figure 9. A comparison between non-treated (on the left) and a treated olive grove (on the right) located in Otranto (Lecce province; coordinates: Lat. 40.138095; Lon. 18.467825) within the "infected" area. It is evident to see the capability of tree restoration provided by the application of the control strategy.

The second case is represented by other farms located in the "infected" area within the provinces of Lecce, Brindisi and Taranto, where trees affected by the bacterium have begun to recover during one or two years. They are scattered on approximately 50 ha and are mainly planted with "Ogliarola salentina" and "Cellina di Nardò" cultivars. The general age of the trees is over 60-70 years but there are cases of farms with century-old trees. All farms showed extensive twig and branch die-backs and various dead trees. In all cases, the dead plant part was removed and the farmers began to apply the biocomplex during spring and summer. In this case also, the farms border areas characterized by a relevant occurrence of X. f. subsp. pauca but the applying of the biocomplex promptly incited a relevant sprouting.

The third case is represented by some farms located in the so called "containment" and "buffer" areas north of the infected one. In such areas, there are cases of farms that began to apply the control strategy upon the uprooting of infected trees and/or to prevent further infections. There are also cases where farmers utilize the protocol as a preventive measure to avoid possible infection by the bacterium.

\section{Conclusions}

The control strategy herein described appears to be a working tool to control X. f. subsp. pauca infections in Salento, and it can be adopted by farmers intending to safeguard the typical olive landscape based on the local cultivars that represent the local heritage. The protocol has been thought to satisfy the biological sustainability requirements of the agro-ecosystem by using an eco-friendly and low-cost support as the biocomplex. The yearly amount of copper released in the environment by means of the protocol application satisfies the current requirements aimed at avoiding the accumulation of copper in the soil [58]. It has been, indeed, calculated that the yearly amount of copper and zinc released by the six treatments in the soil is $0.06 \mathrm{ppm}$ and $0.12 \mathrm{ppm}$, respectively. In addition, all practices are cost-effective for farmers as the methods do not require expensive equipment and/or the purchase of new tools. It has been estimated that the annual cost per tree for six spraying is about 3 euro; for the typical olive farm of Salento that host about 100 trees/ha, the cost is about 300 euro/year. It should be stressed that pathogens that have colonized woody crops are impossible to eliminate from the 
environment, even after intense eradication campaigns lasting many years as already observed in the past in the case of Xanthomonas axonopodis pv. citri, the causal agent of citrus canker, in Florida and Brazil $[59,60]$. A robust pathogen and vector control strategy coupled with widespread and regular application of agronomical techniques could allow to restore, where it is still possible, the olive groves of Salento. This approach would seem particularly useful since alternative strategies to restore the affected areas show difficulties to be implemented by a large part of the territory.

Acknowledgments: This perspective paper was supported by the agreement with Regione Puglia: "Strategie di controllo integrato per il contenimento di Xylella fastidiosa in oliveti pugliesi ed analisi epidemiologiche del complesso del disseccamento rapido dell'olivo (CoDiRO)", and by the projects funded by MIPAAF: "Salvaguardia e valorizzazione del patrimonio olivicolo italiano con azioni di ricerca nel settore della difesa fitosanitaria (SALVAOLIVI)", “Olivicoltura e Difesa da Xylella fastidiosa e da Insetti vettori in Italia” (Oli.Di.X.I.It D.M. 23773 del 6/09/2017).

Conflicts of Interest: The author declares no conflict of interest. The funders had no role in the design of the study; in the collection, analyses, or interpretation of data; in the writing of the manuscript, or in the decision to publish the results.

\section{References}

1. Mittermeier, R.A.; Gil, P.R.; Hoffmann, M.; Pilgrim, J.; Brooks, T.; Mittermeier, C.G.; Lamoreux, J.; Da Fonseca, G.A.B. Hotspots Revisited: Earth's Biologically Richest and Most Endangered Terrestrial Ecoregions; The University of Chicago Press Books: Chicago, IL, USA, 2005; p. 392.

2. Loumou, A.; Giourga, C. Olive orchards: The life and identity of the Mediterranean. Agr. Hum. Val. 2003, 20, 87-95. [CrossRef]

3. Gangale Uzonov, C.; Uzonov, U. Floristic composition of traditional olive orchard on Ioanian coast of south Italy. Bocconea 2003, 16, 783-792.

4. Perrino, E.V.; Calabrese, G.; Ladisa, G.; Viti, R.; Mimiola, G. Primi dato sulla biodiversità della flora vascolare di oliveti secolari in Puglia. Inf. Bot. Ital. 2011, 43, 39-64.

5. Primavera, M.; D'Oronzo, C.; Muntoni, I.M.; Radina, F.; Fiorentino, G. Environment, crops and harvesting strategies during the II millenium B.C.: Resilience and adaptation in socio-economic systems of Bronze Age in Apulia (SE Italy). Q. Int. 2017, 436, 83-95. [CrossRef]

6. Tartaglini, N.; Calabrese, G.; Servadei, L. Ancient olive orchards as high nature value farmland; a shared vision at euro-mediterranean level. In A Multi-Scale and Multi-Level Approach for Conservation of Ancient Olive Orchards in the Euro-Mediterranean Region; La Posta, A., Lacirignola, C., Mimiola, G., Eds.; CIHEAM Mediterranean Agronomic Institute: Bari, Italy, 2012; pp. 27-39.

7. Donno, G. Gli olivi Salentina e Calabrica secondo G. Presta e C. Moschettini. Riv. Storia Agr. 1973, 13, $10-27$.

8. Cortonesi, A. L'olivo nell'Italia medievale. Reti Medievali Rivista 2005, 6, 1-29.

9. Korolevskij, C. Basiliani. In Enciclopedia Italiana; Istituto dell'Enciclopedia Italiana Treccani: Roma, Italy, 1930; Available online: http://www.treccani.it/enciclopedia/basiliani_\%28Enciclopedia-Italiana\%29/ (accessed on 18 May 2020).

10. Cimato, A.; De Rinaldis, G.; Calogiuri, A.L.; Sani, G. Il Germoplasma Olivicolo in Provincia di Lecce; Camera di Commercio Industria, Artigianato e Agricoltura: Lecce, Italy, 2001; p. 89.

11. Cherubini, G. I prodotti della terra: Olio e vino nel Mezzogiorno normanno-svevo. In Olivi e Olio nel Medioevo Italiano; Brugnoli, A., Varanini, G.M., Eds.; CLUEB: Bologna, Italy, 2006; pp. 187-234.

12. Biasco, A. L'olivicoltura Salentina Attraverso i Secoli; Tipografia Degli Agricoltori: Roma, Italy, 1937; p. 16.

13. Donno, G. Sulla scelta delle varietà di olivo nel Salento. Riv. Storia Agr. 1968, 8, 128-152.

14. Del Coco, L.; De Pascali, S.A.; Fanizzi, F.P. NMR-metabolomic study on monovarietal and blend Salento EVOOs including some from secular olive trees. Food Nutr. Sci. 2004, 5, 89-95.

15. Negro, C.; Aprile, A.; Luvisi, A.; Nicolì, F.; Nutricati, E.; Vergine, M.; Miceli, A.; Blando, F.; Sabella, E.; De Bellis, L. Phenolic profile and antioxidant activity of Italian monovarietal extravirgin olive oil. Antioxidants 2019, 8, 161. [CrossRef]

16. Frisullo, S.; Camele, I.; Agosteo, G.E.; Boscia, D.; Martelli, G.P. Brief historical account of olive leaf scorch ("brusca") in the Salento peninsula of Italy and state-of-the-art of the olive quick decline syndrome. J. Plant. Pathol. 2014, 96, 441-449. 
17. Saponari, M.; Boscia, D.; Nigro, F.; Martelli, G.P. Identification of DNA sequences related to Xylella fastidiosa in oleander, almond and olive trees exhibiting leaf scorch symptoms in Apulia (southern Italy). J. Plant. Pathol. 2013, 95, 668 .

18. Cariddi, C.; Saponari, M.; Boscia, D.; De Stradis, A.; Loconsole, G.; Nigro, F.; Porcelli, F.; Potere, O.; Martelli, G.P. Isolation of Xylella fastidiosa strain infecting olive and oleander in Apulia, Italy. J. Plant. Pathol. 2014, 96, 425-429.

19. Scholten, R.; Martinez Sanchez, L.; Hornero, A.; Navas-Cortes, J.A.; Zarco-Tejada, P.J.; Beck, P.S.A. Monitoring the impact of Xylella on Apulia's olive orchards using MODIS satellite data supported by weather data. In Proceedings of the 2nd European Conference on Xylella fastidiosa, Ajaccio, France, 29-30 October 2019; Available online: http://www.efsa.europa.eu/sites/default/files/event/191029-xylella/S6.P1_BECK.pdf (accessed on 18 May 2020).

20. Almeida, R.P.P.; Nunney, L. How do plant diseases caused by Xylella fastidiosa emerge? Plant. Dis. 2015, 99, 1457-1467. [CrossRef] [PubMed]

21. Bebber, D.P.; Holmes, T.; Gurr, S.J. The global spread of pests and pathogens. Glob. Ecol. Biogeogr. 2014, 23, 1398-1407. [CrossRef]

22. Marcelletti, S.; Scortichini, M. Xylella fastidiosa CoDiRO strain associated with olive quick decline syndrome in southern Italy belongs to a clonal complex of the subspecies pauca that evolved in Central America. Microbiology 2016, 162, 2087-2098. [CrossRef]

23. Giampetruzzi, A.; Saponari, M.; Loconsole, G.; Boscia, D.; Savino, V.N.; Almeida, R.P.P.; Zicca, S.; Landa, B.B.; Chacon-Diaz, C.; Saldarelli, P. Genome-wide analysis provides evidence on the genetic relatedness of the emergent Xylella fastidiosa genotype in Italy to isolates from Central America. Phytopathoogy 2017, 107, 816-827. [CrossRef]

24. Fierro, A.; Liccardo, A.; Porcelli, F. A lattice model to manage the vector and the infection of Xylella fastidiosa on olive trees. Sci. Rep. 2019, 9, 8723. [CrossRef]

25. Sosnowsky, M.R.; Fletcher, J.D.; Daly, A.M.; Rodoni, B.C.; Viljanen-Rollinson, S.L.H. Techniques for the treatment, removal and disposal of host material during programmes for plant pathogen eradication. Plant Pathol. 2009, 58, 621-635. [CrossRef]

26. Martelli, G.P. The current status of olive quick decline syndrome of olive in southern Italy. Phytoparasitica 2016, 44, 1-10. [CrossRef]

27. Hopkins, D.L. Xylella fastidiosa: Xylem-limited bacterial pathogen of plants. Annu. Rev. Phytopathol. 1989, 27, 271-290. [CrossRef]

28. European Food Safety Authority (EFSA). EFSA Scientific report on the update of a database of host plants of Xylella fastidiosa. EFSA J. 2016, 14, 4378-4418. [CrossRef]

29. Redak, R.A.; Purcell, A.H.; Lopes, J.R.S.; Blua, M.J.; Mizel, L.R.F., III; Andersen, P.C. The biology of xylem fluid-feeding insect vectors of Xylella fastidiosa and their relation to disease epidemiology. Annu. Rev. Entomol. 2004, 49, 243-270. [CrossRef] [PubMed]

30. Saponari, M.; Loconsole, G.; Cornara, D.; Yokomi, R.K.; De Stradis, A.; Boscia, D.; Bosco, D.; Martelli, G.P.; Krugner, R.; Porcelli, F. Infectivity and transmission of Xylella fastidiosa by Philaenus spumarius (Hemiptera: Aphrophoridae) in Apulia, Italy. J. Econ. Entomol. 2014, 107, 1316-1319. [CrossRef] [PubMed]

31. Dowdle, W.R. The principle of disease elimination and eradication. Bull. World Health Organ. 1998, 76 (Suppl. 2), 22-25.

32. Strona, G.; Carstens, C.J.; Beck, P.S.A. Network analysis reveals why Xylella fastidiosa will persist in Europe. Sci. Rep. 2017, 7, 71. [CrossRef]

33. Aylword, R.B.; Birmingham, M. Eradicating pathogens. The human story. Brit. Med. J. 2005, 331, 1261-1262. [CrossRef] [PubMed]

34. Purcell, A.H.; Hopkins, D.L. Fastidious xylem-limited bacterial plant pathogens. Annu. Rev. Phytopathol. 1996, 34, 131-151. [CrossRef]

35. Kirkpatrick, B.; Anderson, P.; Civerolo, E.; Jones, D.-D.; Purcell, A.H.; Smith, R.; Vargas, C.; Weber, E. Evaluation of bactericides and modes of delivery for managing Pierce's disease. In Proceedings of the Pierce's Disease Research Symposium, Coronado, CA, USA, 8-11 December 2003; pp. 101-103.

36. Bleve, G.A.; Altomare, C.; Vurro, M.; Maiorano, G.; Cardinali, A.; D’Antuono, I.; Marchi, G.; Mita, G. In vitro activity of antimicrobial compounds against Xylella fastidiosa, the causal agent of the olive quick decline syndrome in Apulia (Italy). FEMS Microbiol. Lett. 2018, 365. [CrossRef] 
37. Gatto, C.; De Vincenti, L.; Cappitelli, F.; D’Attoma, G.; Saponarui, M.; Villa, F.; Forlani, F. Non-lethal effect of N-Acetylcysteina on Xylella fastidiosa strain De Donno biofilm formation and detachment. Microorganisms 2019, 7, 656.

38. Baldassarre, F.; Tatulli, G.; Vergaro, V.; Mariano, S.; Scala, V.; Nobile, C.; Pucci, N.; Dini, L.; Loreti, S.; Ciccarella, G. Sonication-assisted production of phosetyl-Al nanocrystals: Investigation on human toxicity and in vitro antibacterial efficacy against Xylella fastidiosa. Nanomaterials 2020, 1174. [CrossRef]

39. Zicca, S.; De Bellis, P.; Masiello, M.; Saponari, M.; Saldarelli, P.; Boscia, D.; Sisto, A. Antagonistic activity of olive endophytic bacteria and of Bacillus spp. strains against Xylella fastidiosa. Microbiol. Res. 2020, 236, 126467. [CrossRef] [PubMed]

40. Navarrete, F.; De La Fuente, L. Zinc detoxification is required for full virulence and modification of the host leaf ionome by Xylella fastidiosa. Mol. Plant. Microbe Interact. 2015, 28, 497-507. [CrossRef] [PubMed]

41. Cobine, P.A.; Cruz, L.F.; Navarrete, F.; Duncan, D.; Tygart, M.; De La Fuente, L. Xylella fastidiosa differentially accumulates mineral elements in biofilm and planktonic cells. PLoS ONE 2013, 8, e54936. [CrossRef] [PubMed]

42. Scortichini, M.; Chen, J.; De Caroli, M.; Dalessandro, G.; Pucci, N.; Modesti, V.; L'Aurora, A.; Petriccione, M.; Zampella, L.; Mastrobuoni, F.; et al. A zinc-copper-citric acid biocomplex shows promise for control of Xylella fastidiosa subsp. pauca in olive trees in Apulia region (southern Italy). Phytopath. Medit. 2018, 57, 48-72. [CrossRef]

43. Girelli, C.R.; Del Coco, L.; Scortichini, M.; Petriccione, M.; Zampella, L.; Mastrobuoni, F.; Cesari, G.; Bertaccini, A.; D'Amico, G.; Contaldo, N.; et al. Xylella fastidiosa and olive quick decline syndrome (CoDiRO) in Salento (southern Italy: A chemometric $1 \mathrm{H}-\mathrm{NMR}$-based preliminary study on Ogliarola salentina and Cellina di Nardò. Chem. Biol. Technol. Agric. 2017, 4, 25. [CrossRef]

44. Girelli, C.R.; Angilè, F.; Del Coco, L.; Migoni, D.; Zampella, L.; Marcelletti, S.; Cristella, N.; Marangi, P.; Scortichini, M.; Fanizzi, F.P. ${ }^{1} \mathrm{H}-\mathrm{NMR}$ metabolite fingerprinting analysis reveals a disease biomarker and a field treatment response in Xylella fastidiosa subsp. pauca-infected olive trees. Plants 2019, 8, 115. [CrossRef]

45. Scortichini, M.; Migoni, D.; Angilè, F.; Del Coco, L.; Girelli, C.R.; Zampella, L.; Mastrobuoni, F.; Fanizzi, F.P. Xylella fastidiosa subsp. pauca on olive in Salento (southern Italy): Infected trees have low in planta micronutrient content. Phytopath. Medit. 2019, 58, 39-48. [CrossRef]

46. Oliver, J.E.; Sefick, S.A.; Parker, J.K.; Arnold, T.; Cobine, P.A.D.L.F.L. Ionome changes in Xylella fastidiosa-infected Nicotiana tabacum correlate with virulence and discriminate between subspecies of bacterial isolates. Mol. Plant. Microbe Interact. 2014, 27, 1048-1058. [CrossRef]

47. Cornara, D.; Saponari, M.; Zellinger, A.R.; De Stradis, A.; Boscia, D.; Loconsole, G.; Bosco, D.; Martelli, G.P.; Almeida, R.P.P.; Porcelli, F. Spittlebugs as vectors of Xylella fastidiosa in olive orchards in Italy. J. Pest Sci 2017, 90, 521-530. [CrossRef]

48. Cornara, D.; Cavalieri, V.; Dongiovanni, C.; Altamura, G.; Palmisano, F.; Bosco, D.; Porcelli, F.; Almeida, R.P.P.; Saponari, M. Transmission of Xylella fastidiosa by naturally infected Philaenus spumarius (Hemiptera, Aphrophoridae) to different host plants. J. Appl. Entomol. 2017, 141, 80-87. [CrossRef]

49. Cornara, D.; Bosco, D.; Fereres, A. Philaenus spumarius: When an old acquaintance becomes a new threat to European agriculture. J. Pest. Sci. 2018, 91, 957-972. [CrossRef]

50. Di Serio, F.; Bodino, N.; Cavalieri, V.; Demichelis, S.; Di Carolo, M.; Dongiovanni, C.; Fumarola, G.; Gilioli, G.; Guerrieri, E.; Picciotti, U.; et al. EFSA Collection of data and information on biology and control of vectors of Xylella fastidiosa; EFSA Supporting Publication: Parma, Italy, 2019; p. 102. [CrossRef]

51. Thomson, V. Spittlebug indicators of nitrogen-fixing plants. Ecol. Entomol. 1994, 19, 391-398. [CrossRef]

52. Santilli, E.; Lombardo, L.; Varlaro, M.E.; Nannelli, R.; Gagnarli, E.; Briccoli Bati, C. Effectiveness of the GAEC cross compliance standard maintanance of olive groves in good vegetative condition in avoiding the deteriorations of habitats and land abandonment. Ital. J. Agron. 2011, 6, e15. [CrossRef]

53. Calabrese, G.; Ladisa, G.; Proscia, A.; Simeone, V.; Kalaitzis, P.; Bazakos, C.; Fragkostefanakis, S. Guidelines for the Management of Biodiversity in Century-Old Olive Groves; CIHEAM-Mediterranean Agronomic Institutes: Bari, Italy; Chania, Greece, 2012; p. 52.

54. Gucci, R.; Cantini, C. Pruning and Training Systems for Modern Olive Growing; Csiro Publishing: Clayton, Australia, 2000; p. 224.

55. Ciervo, M. The olive quick decline stndrome (OQDS) diffusion in Apulia region: An apparent contradiction according to the agricultural model. Belgeo 2016, 4. [CrossRef] 
56. Berendson, R.L.; Pieterse, C.M.J.; Bakker, P.A.H.M. The rhizosphere microbiome and plant health. Trends Plant. Sci. 2012, 17, 478-486. [CrossRef]

57. Giovannetti, G.; Polo, F.; Nutricato, S.; Masoero, G.; Nuti, M. Efficacy of a commercial symbiotic bio-fertilizer consortium for mitigating the olive quick decline syndrome (OQDS). J. Agron. Res. 2019, 2, 1. [CrossRef]

58. European Commission Implementing Regulation (EU) 2018/1981. Renewing the Approval of the Active Substances Copper Compounds, as Candidates for Substitution, in Accordance with Regulation (EC) No 1107/2009 of the European Parliament and of the Council Concerning the Placing of Plant Protection Products on the Market, and Amending the Annex to Commission Implementing Regulation (EU); European Commission: Brussels, Belgium, 2018.

59. Schubert, T.S.; Rizbi, S.A.; Gottwald, T.R.; Graham, J.H.; Dixon, W.N. Meeting the challenge of eradicating citrus canker in Florida-again. Plant. Dis. 2001, 85, 340-356. [CrossRef]

60. Behlau, F.; Fonseca, A.E.; Belasque, G., Jr. A comprehensive analysis of the Asiatic citrus canker eradication program in São Paulo state, Brazil, from 1999 to 2009. Plant. Pathol. 2016, 65, 1390-1399. [CrossRef]

(C) 2020 by the author. Licensee MDPI, Basel, Switzerland. This article is an open access article distributed under the terms and conditions of the Creative Commons Attribution (CC BY) license (http://creativecommons.org/licenses/by/4.0/). 